REDRESSING THE METAPHYSICS OF NUDITY

\title{
REDRESSING THE METAPHYSICS OF NUDITY: \\ NOTES ON SENECA, ARENDT, AND DIGNITY
}

\author{
ANDREW BENJAMIN
}

IF THERE IS A GENERAL PROJECT that orientates these notes then it can be located in what can be described as the question of the ethical subject. ${ }^{1}$ There is of course an initial doubling within this question. The subject of the ethical belongs, in the first instance, to a topos or a field of concerns, the subject area of the ethical. In the second, it pertains to the subject within that field. The latter is the self or the moral agent. However, with both these determinations of the ethical subject there is a set of metaphysical considerations that have to be brought out. What is important in both is the presence of differing sets of relations, thus differing modes of relationality. These are the relations in which the question of the individual is present as that which can be understood in terms of processes of individuation. Within such processes there is a general question of whether the subject and the ethical can be separated. What can always hold, as one possibility, would be that positioning of the subject in which the connection to the ethical involved no more than a contingent relation. The subject would arrive stripped of original ethical concerns. (This is the position that forms - and is formed by - one particular determination within what will be called henceforth a metaphysics of nudity.) The alternative would be to argue that the ethical is not a contingent predicate, but that the subject, the moral agent, is ethical from the start. As such, reflection, now as the recognition of that situation, would then have to form a fundamental part of the overall 


\section{REDRESSING THE METAPHYSICS OF NUDITY}

argument. (Indeed it will be in terms of the precondition for the recognition of virtue that dignity appears.) Were the always already present relation between the ethical and the subject to pertain - a set-up in which this particular construction of the ethical subject predominated - then the ethical would be inscribed as a concern at the center of any development of a sustained philosophical anthropology. Virtue and being would be interarticulated. That interarticulation would have what can be described as an original force, ${ }^{2}$ namely, that the ethical was an original condition rather that a mere contingent addition to human being.

The connected point of inquiry therefore concerns the subject as moral agent. It involves the question of the extent to which subject positions precede relationality or are simply produced as such. At work here is the temporality of relationality. The complexity of this predicament is already located in Hannah Arendt's claim made at the beginning of The Human Condition that "men, not man, live on the earth and inhabit the world." 3 The question that follows from this formulation concerns the status of the subject given that any singularity, "man" in this instance, would itself always be an after-effect of an initial plurality, here "men." (What then of the original relation?) Moreover, and this is to mark in advance the limit of Arendt's own thinking, what has to be taken up in addition is the nature of this original positioning. What is the status of an already present and thus preceding plurality? ${ }^{4}$ (A question that arises once the temporality of relationality figures as a central part of any concern with the ethical subject.) Part of what has to be addressed in what follows is the problem of how plurality, individuality, and individuation are to be understood. That problem can be given a more precise location by noting its presence in the opening of the Epistulae morales; indeed, it is present in the first line of Letter 1. 


\section{REDRESSING THE METAPHYSICS OF NUDITY}

Seneca demands of Lucilius vindica te tibi ("claim yourself for yourself," Sen. Ep.1.1). ${ }^{5}$ A position that also occurs in fragments from De clementia that were present in a letter by Hildebert of Tours, in which the Prince who shows mercy, "the good prince," is defined thus: Bonus princeps sibi dominator ("A good prince masters himself," Sen. Clem. 448-49). Both formulations open a field of inquiry. Advanced within them is not just the project and possibility of self-fashioning but its locus, namely, the self as defined by its being self-referring. (The connection and interdependence between them cannot be overlooked.) Hence the issue that has to be pursued, almost as a necessary perquisite for any encounter with Arendt's identification of an initial form of plurality, concerns the self that is given within the actual possibility of self-definition. Remembering that the status of the subject - what will continue to be understood as the ethical subject and thus the way it is thought by Seneca (and subsequently by Arendt) — cannot be extricated from its inscription within the particular determination that the temporality of relationality has in any one instance. As has already been intimated there are two importantly different questions: Is relationality prior to individuation? Or is a relation that which occurs, and can only occur, between two already individuated subjects?

A beginning can be made, therefore, with the problem of singularity, knowing in advance that a simple evocation of the subject as existing merely in simpliciter cannot be accurate. Suggested by the very possibility of posing the questions noted above is that a form of 
complexity will have always obtained. Note the following formulation from Epistulae morales (120.22):

praeter sapientem autem nemo unum agit, ceteri multiformes sumus

No one can act as a unified/singular person except the wise; the rest of us take on different forms.

The self as a concern for itself, what amounts to the project of self-care, is clear from this formulation. Claims of the primacy of the care of self cannot be taken as an end. ${ }^{6}$ What is raised as a question is the nature of the self that figures within such a formulation and that gives rise to the ensuing question: What thinking of the ethical subject can be found within it? Overcoming the possibility of "different forms," perhaps what would amount to the wearing of masks, takes place to the extent that the occurrence of wisdom is commensurate with processes of singularization. And yet, even the mask can singularize. In Polybius' description of Roman funeral rites in which the image of the dead were worn

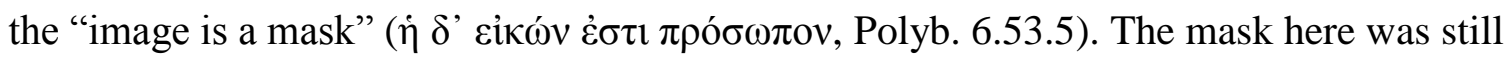
an unequivocal presentation of the deceased person. The mask therefore did not mask. In more general terms, therefore, the singular occurs to the extent that the multiple dissipates. (The latter can itself take many forms.) Staged here is, of course, the problem of continuity and constancy. The self, the self of self-care, that is defined by the continuity of constancy, is wise. Wisdom and virtue are positioned in relation to each other. They are inseparable. Virtue is "free, inviolable, unmoved, unshaken" and thus it 


\section{REDRESSING THE METAPHYSICS OF NUDITY}

"steels against the blows of chance" (Sen. Constant. 5.4). Hence the description in De vita beata that "the highest good is a mind that scorns the happenings of chance, and rejoices only in virtue" (Summum bonum est animus fortuita despiciens, virtute laetus, Sen. De vita beata 4.2). Equally, what can be located here is the expression of "liberty." Liberty is not the free engagement with what is, equally it does not involve having to tolerate what is. Liberty is neither directly worldly nor world referring. Rather liberty, for Seneca, is a state of the soul. It is part of a process of individualizing. Hence liberty is defined thus (Sen. De vita beata 19.2):

libertas est animum superponere iniuriis et eum facere se ex quo solo sibi gaudenda veniant.

liberty is having a soul that rises above injury and makes itself the only source from which its pleasure comes. ${ }^{7}$

What remains for Seneca, though only as position bereft of argumentation, is the assumption that the exercise of liberty is unproblematic. It is simply the exercise of the soul and thus there cannot be any form of constraint. (As will be suggested at a later stage this aspect of his argumentation delimits his conception of the ethical subject in ways that announce its own limits. Limits would emerge because constraints are built into the problem of freedom once freedom is understood as involving the actualization of a potentiality rather than the simple affirmation of self. The latter is the self of self-care.) 


\section{REDRESSING THE METAPHYSICS OF NUDITY}

Central to this overall development of the connection between wisdom and virtue is the presence of the wise person as exemplary. Wisdom is "the art of life" (ars ... vitae est, Sen. Ep. 117.12). ${ }^{8}$ Though equally, prima ars hominis est ipsa virtus ("man's primary art is virtue itself," Sen. Ep. 92.10). Hence the continual link between virtue and wisdom. (And it should be remembered that virtue is not part of a straightforward calculus. Virtue is an activity that has no specific outcome "apart from the virtues themselves" [Sen. Clem. 1.1). This is the setting within which the exemplary figure creates an image. ${ }^{9}$ Indeed, as will be noted, this image sets the measure.

The ineliminability of the image and its exemplary force gives rise to an inevitable question: that is, what does it mean, however, to follow an image? Could an image, an image that was itself already assumed to be one of moral worth, determine in advance how a life is to be lived? It would be lived, of course, after having received such an image. Were both questions to be answered in the affirmative, then what emerges is a set up allowing for lives to be molded — a form of self-molding — such that virtue and thus the good life are able to be formed and, as significantly, the self would have lent itself to self-forming. The frame within which these processes occur is structured by the relation between a determining image and the capacity of a self to mold itself in relation to it. The important point is that there cannot be self-molding as though such an activity was simply abstract; there will always have been an image, hence there will always have been a relation. What this means, in addition, is that virtue and the good life - the latter as the life in which the greatest good obtains - are themselves able to be actualized by a subject for a subject. Within such a setting there are two unannounced, though pivotal, prerequisites. The first is that the locus of virtue is the self as an isolated and isolatable 


\section{REDRESSING THE METAPHYSICS OF NUDITY}

entity. (This is the how the ethical subject, in this context, is being thought.) Given this condition it follows that the self (or moral agent) is an isolated singularity. And, significantly, has to have been produced as such. The singular self is an act of production. What is raised thereby is the question of how what counts as the singular is to be understood. (And again it should be noted that while individual responsibility inevitably involves a conception of the singular subject, it remains an open question as to how that singularity emerges — is it assumed or produced? — and therefore what would be the apposite philosophical framework within which it were to be interpreted.)

The second prerequisite concerns the presence of a relationship between the image and the self. Again, there is the question of how the elements of that relationship are themselves to be understood. As a beginning, the constant allusion in these opening questions needs to be identified. The point of reference is of course the account of Seneca's suicide in Tacitus' Annals. ${ }^{10}$ While the figure of Seneca in the Annals is at best ambiguous, it is still the case that Seneca's own self-conception can be attributed an important position since it captures the project of self-creation that occurs in his own writings. Within the context of this historical self-presentation his concerns were clear. As Tacitus recounts events, Seneca wished to write his own will. Once this was refused, it was still possible that some other aspect of his life could be bequeathed to his "friends." At stake here is how Seneca understood not just his legacy, but the actual content to be conveyed. This other possibility, thus the specification that his legacy was to have, is formulated by Tacitus in the following terms (Tac. Ann. 15.62): 


\section{REDRESSING THE METAPHYSICS OF NUDITY}

he bequeathed to them the only, but still the noblest [pulcherrimum] possession yet remaining to him, the image of his life [imaginem vitae suae], which, if they remembered [si memores essent], they would win a name for moral worth and friendship defined by constancy [constantis amicitiae].

His life had an image or pattern. And it must be noted that it is "his" (suae) life. His life would be exemplary. It would form the pattern. As significantly that pattern or image could be remembered. Remembering as a form of following, the legacy as conveyed, would allow for the attribution of moral worth to those who remembered it. In addition, it would form, so Seneca's proclamation runs, the basis of genuine and thus constant friendships.

Tacitus is right, given the frame of reference, to describe "life" here in terms of an image or pattern. This is the term that would have to be used precisely because it is one that accords with the language of the mold and thus with the activity of forming or molding. The former allows for that activity to take place. The image has a determining effect. In Epistulae morales 92, after having conceded that the human has a flawed nature, Seneca goes on to note that this propensity for the bad can be overcome. ${ }^{11}$ And yet, even excising it does not lead directly to the good. While a type of determination prevails, it is linked to a specific form of contingency. Hence the complex formulation that such a person, non est adhuc bonus, sed in bonum fingitur ("is not yet good, but is being molded to goodness"). This description of the self is reinforced by the reference to Vergil that occurs a few lines later in the Letter. ${ }^{12}$ The passage in question deploys a line 


\section{REDRESSING THE METAPHYSICS OF NUDITY}

from the Aeneid that evokes the person "in whose body virtue and the soul are present" (si cui virtus animusque in corpore praesens) to then add that such a person is "equal to the gods" (deos aequat). The question, of course, is what does "equal" mean in this context, ${ }^{13}$ noting of course that the question of equality has to be limited by possibility.

In the De vita beata Seneca suggests that the recognition that "true happiness" is "based on virtue" allows for a stand to be taken in relation to both vice and the good in which one - the stand taker-may "embody God" (deum effingas). That possibility is of course mediated from the start by the addition qua fas est ("as far as is allowed," Sen. De vita beata 16.1$).{ }^{14}$ What is meant by equality is therefore far more complex than would be provided by a response that was no more than the simple assertion of an assumed form of sameness or identity. As a result, any attempt to engage this problem - the meaning of equality - can only be given once it can be assumed that the human is not identical to the gods but a process of making and molding allows the imperfect to perfect itself. If, as Vergil wrote, such is a person is the one "in whose body virtue and the soul are present" then what matters is the manifestation of that quality. In other words, what is at stake is a body housing elements whose initial presence allows for perfection and as such virtue has to be allowed to emerge. While the formulations are in both instances different, there are two references to the process of forming and imitation that occur in De vita beata and that are central to the argument being developed here. Both provide further insight into Seneca's continual formulation and reformulation of what in the context of his writings the ethical subject is taken to be.

In the first instance, and again after conceding both the possibility and reality of corruption, what allows humans a way out is their status as molders or formers of their 


\section{REDRESSING THE METAPHYSICS OF NUDITY}

own lives (artifex vitae, Sen. De vita beata 8.3). The second is more extended. After a general argument concerning the relationship between human activity and nature, the "happy life" is taken to be the same thing as living "according to nature" (secundum naturam, Sen. Ep. 41.9, 121.3). Wisdom emerges in this context. Seneca comes to define wisdom in relation to the process in which human beings form themselves according to the law of nature. From this there is the general though fundamental conclusion to be drawn, namely, that the "happy life ... is a life that is in harmony with its own nature" (beata est ergo vita conveniens naturae suae, Sen. De vita beata 3.2-4). The important question here is why "nature" is qualified such that what is at stake is living in relation to the nature that is proper not just to life, but to the life of a subject that is always specific. (Recalled here is, of course, the way Seneca's legacy is an "image" that would allow lives to be lived in accord with it.) What sets the measure is therefore internal to life. Nature, if only in this instance has an externality that controls what is taking place within life. It is as though life in having its own "nature" has its own sense of propriety. The telos of life is therefore internal to life. The immediate contrast is of course with the formulations of Zeno of Citium and Chrysippus as they both appear in passages cited by Diogenes Laertius (7.86-90). Zeno's formulation is: "Living in agreement with nature"

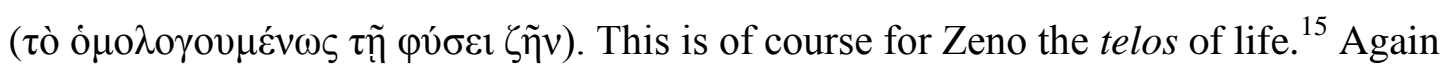
following the formulation in Diogenes Laertius, for Chrysippus the nature of the

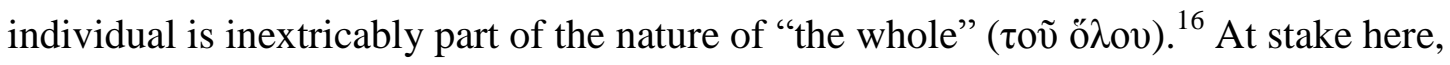
therefore, is a thinking of the relationship between the human and the natural in terms set by the interplay of the microcosm and the macrocosm. The latter is exemplified throughout Seneca's writings. Hence, "God's place in the universe corresponds to the 


\section{REDRESSING THE METAPHYSICS OF NUDITY}

soul's relation to man" (Ep. 65.24) and then, "all that you behold, that which comprise both God and man is one [unum est]—we are parts of one great body [membra sumus corporis magni] (95.52). While self-molding is the human project, God is self-made. The well-known formulation found in Lactantius' quotation from Seneca's Exhortations makes this clear: deus ipse se fecit. ${ }^{17}$

The problem that arises here concerns the extent to which there might be a tension between two different settings. In the first instance, it is a setting delimited by the relation of macrocosm/microcosm as that which defines the connection between the human and God. In the second, the setting is created by the attribution of a "nature" that is proper to human being. The tension arises because while both pertain to the nature of human being, the second does not depend upon God for that self-definition. What did Seneca mean in the Natural Questions when in response to the question "What is important?", one answer was "to be mindful of being a man" (hominis meminisse, Sen. Q Nat. 3.praef.15.) What was it of which one was mindful? Rather than address this question directly it is perhaps more important to start with the relation to God. It is not as though for Seneca this is an arbitrary relation. In Letter 41 God is described (remember that Seneca is writing to Lucilius) as "within you" (intus est, Sen. Ep. 41.1). Again the Aeneid is cited. Vergil aids by allowing a further clarification. Vergil introduces a limitation since who the Gods are is "uncertain" (incertum). And yet, despite this uncertainty what cannot be disputed is that "your soul will be deeply affected by a certain religious intimation"position advanced within the imagery of the sun. The human is touched by God, the way the ground is warmed by the sun's rays. Those rays still form part of the sun from which they came. ${ }^{18}$ Touching they imbue a certain quality. Even within this setting the human 


\section{REDRESSING THE METAPHYSICS OF NUDITY}

has a determined outcome. The human is "born" with a good that is there to be realized. That possibility can occur because of that which is proper to human being. (Hence a specific modality of the proper informs the ethical subject.) The formulation Seneca provides for this set up has an exacting concision, proprium hominis est. As to what this quality is, once again Seneca's language is precise: "It is soul and reason brought to perfection in the soul. For man is a reasoning animal" (animus et ratio in animo perfecta. rationale enim, animal est homo, Ep. 41.8). At this point in the Epistle in response to the question of what is it that reason demands of the human being, the answer comes full circle: "to live according to his own nature" (secundum naturam suam vivere). Again, the conception of nature that arises here is delimited. It is the nature of human being. Nature has been internalized. (Though equally, if the position noted in Tacitus is retained, it will also be the case that Seneca's legacy is delimited by his image. The generality of human being here is also is the singularity of Seneca.) There is, however, an important additional point that needs to be made. For Seneca, what is meant by the living out of this nature, equally of taking the exemplary subject as setting a similar measure, is that to the extent its lived presence can be either observed or remembered, then such activities, such modes of life, endure as unproblematically realizable. The presence of virtue is clear rather than irredeemably hidden. The response to the virtue is itself located within a setting in which one dignified subject encounters another. Clarity obtains. Seneca notes, "For virtue, though obscured [obscura] is never concealed, but always gives signs of its presence [sed mittit sui signa]: whoever has dignity [dignus] can trace her out by her footsteps" (Tranq. 3.7). Signs take the place of the concealed. Virtue, while not self-evident, is present in ways that can be followed. Virtue can be tracked. It is possible to follow that which has 


\section{REDRESSING THE METAPHYSICS OF NUDITY}

exemplary force. The having of dignity allows virtue to be recognized. There is a mode

of recognition that sustains dignity. Virtue, in other words, has it own form of enargeia. ${ }^{19}$ The presentation of virtue and the virtuous has to be thought in terms of immediacy and as a result virtue is always continuous with its own actuality. While the subject is located within the structure created by the microcosm/macrocosm in which God has a necessary presence, it is also the case that the ethical subject can be attributed qualities almost independently of that connection. The latter involves the effective presence of reason. The complexity that this engenders can be located in the difficulty of thinking a relation between the human and the divine that is not structured by what might be described as the logic of incarnation even though that is precisely what is occurring here. ${ }^{20}$

What has to be taken up next is the question of who this subject is. While dignity may be there in what is taken to be the nature of human being, what is equally as true is that dignity is both an intrinsic quality and an actual quality. There is no impediment to dignity's actualization. It is a quality, a potentiality, of human being, though it is one in which being human is always individuated as a singular subject. Its universality resides in the human as a "reasoning animal" and thus not as a human within any form of collectivity that would allow for or restrict dignity's actual present. Dignity would be linked to a state of any one individual soul; moreover, dignity would then continue to be defined, as a result, in terms of the sovereign subject. What is beginning to emerge is the way the ethical subject is being thought. 


\section{REDRESSING THE METAPHYSICS OF NUDITY}

The question is how is this subject, the ethical subject, here the one open to virtue, to be understood. In the De beneficiis a response to this question is provided in such a way as to strip away any outer coatings this self may have had in order that the human itself emerge. What occurs as a result is what might be described as that specific thinking of singularity that involves the interarticulation of the singular and nudity. One is present with the other. Taken together they construct a specific modality within a more generalized metaphysics of nudity. This occurs a number of times in Seneca's writings. As part of an attempt to delimit the appearance of anger he asks, what if (the soul) "could be shown naked" (nudus ostenderetur, De ira 36.2)? Then, more significantly, in a passage addressing questions of slavery, the address occurs in a way that saves the slave insofar as the slave is linked, as will be noted, to the "right of man," while condemning the slave, at the same time, to perpetual slavery since slavery, the arguments then continues, does not restrict the reciprocity of exchange that defines an economy of benefits. Seneca's formulation is exact (De beneficiis 18.2):

Moreover, he who denies that a slave can sometimes give a benefit to his master is ignorant of the rights of man [praeterea servum qui negat dare aliquando domino beneficium, ignarus est iuris humani]; for, not the status, but the intention, of the one who bestows is what counts. No one is precluded from virtue [nulli praeclusa virtus est]; it is open to all, admits all, invites all, the freeborn and the freedman, the slave and the king, and the exile; neither family nor fortune determines its choice - it is satisfied with the naked human being [nudo homine contenta est]. 


\section{REDRESSING THE METAPHYSICS OF NUDITY}

The argument as a whole concerns the logical structure of beneficence. That structure involves a form of reciprocity in which intentionality, that is, the operation of the will to give and receive, has to endure as paramount. Indeed, as already noted above, it supersedes the determination of any one position — for example, slave, king, freebornwithin the economy that it creates. Slaves can be beneficent. This can occur precisely because their position as slaves, the argument has to be, is irrelevant to the effective functioning of that logic. ${ }^{21}$ This is clear from the way the formulation of the position is continued by Seneca in the De beneficiis (18.3):

It is possible for a slave to be just, it is possible for him to be brave, it is possible for him to be magnanimous; therefore it is possible also for him to give a benefit, for this also is one part of virtue.

What emerges is of course the apparently virtuous slave. There is, of course, a presupposition here. Moreover, it is a presumption on which the overall position depends, namely the claim that the subject of virtue is "the naked human being." And yet, the metaphysics of nudity, in its very formulation, yields what might be positioned as a countermeasure. ${ }^{22}$ In place of the necessity of nudity's link to a form authenticity, there is Arendt's recognition of its inherent limitation. Part of what allowed for the advent of the totalitarian is that, in her terms, "the world found nothing sacred in the abstract nakedness

of being human." 23 (The use of the term "sacred" should be noted here.) It should also be noted that her discussion of Heidegger and "care" that occurs in The Life of the Mind 


\section{REDRESSING THE METAPHYSICS OF NUDITY}

makes one reference, following Heidegger, to the "nakedness" of the being who discovers itself thrown into the world. ${ }^{24}$ The argument is going to be that mere "throwness," the subject of pure exposure, opens up a need to think care in ways that a response to what this subject elicits does not depend upon exposure understood in terms of simple (literal) nakedness. There will have to be more. That possibility alludes, almost as a matter of course, to the inscription of an original quality that will always been there with this "nakedness" even though it is not reducible to it. To which it should be added that there are different possibilities within such a set-up. Emmanuel Levinas, for example, draws a distinction between what he refers to as "the nudity of the face" (la nudité $d u$ visage) and literal nudity. ${ }^{25}$ The latter is the result of a dévoilement. The nudity of the face is that which is given within relationality prior to the emergence of instructions to act. Here, in contrast to Seneca, there is a conception of nudity that is defined by the insistence of relationality. Nudity is there as a given condition. While not the same as Arendt's own arguments, this position does, at the very least, through the insistence on relationality and the implicit critique of the isolated singular subject establish a point of connection between Levinas and Arendt. ${ }^{26}$

Arendt's engagement with the ethical subject within Seneca (and thus by extension within versions of Stoicism both ancient and contemporary) is not to be found in the few allusions or references to either Seneca or Stoicism that occur in her writings. On the contrary, it can be located in her implicit commitment to what might be described as another strand of Roman thought. If her lead were followed, it would be Roman thought's other possibility. It occurs in her understanding of how that mode of thinking conceived of life. She wrote: 


\section{REDRESSING THE METAPHYSICS OF NUDITY}

Thus the language of the Romans, perhaps the most political people we have known, used the words 'to live' and 'to be among men' \{inter homines esse $\}$... as synonyms. ${ }^{27}$

The contrast is not to be thought simply in terms of an opposition between clothed and unclothed; if there is a point at which there is a redress to Seneca's evocation of nudity then it can located in her Latin formulation inter homines esse. However, it is essential to be precise here. While it may not always be pursued with systematic rigor, Arendt's thinking of the ethical subject is defined not by the human as such but by the assertion of a form of relationality. Within the formulation inter homines esse what has to be privileged is the "inter." What that means, as Peg Birmingham has argued, is that "The right of sovereignty, individual and collective, is replaced with the right to belong to an organized political space with its inherent plurality of actors. ${ }^{, 28}$ The implication is that entry into this plurality cannot be assumed. There is a place of belonging. The commonality in question is only ever ontological. Dignity defines the potentiality of human being within it. Asserting presence, occupying what Arendt refers to as the "space of appearance," is a claim about the "inter" and thus also a claim about what it means to figure within it. ${ }^{29}$ As such that figuring becomes the affirmation of a form of relationality. (Equally the refusal of relationality is not the singular but the production of the singular as existing within a constituted without relation. ${ }^{30}$ An act of constitution that marks in advance singularity as an after-effect of a constituting act.) As a consequence it cannot be a self either as a singular object who returns to its self either through self-making or the 


\section{REDRESSING THE METAPHYSICS OF NUDITY}

processes resulting from remembering/imitating. There cannot be acts of self-constitution because there are only ever selves within relationality or excluded from it. Both moments are essential loci of activity. Place is constituted and thus reconstituted by and through the ways modes of inclusion and exclusion occur. An important additional point here is that the place from which exclusion would occur is the space understood as the locus of "speech and action." 31 Given that for Arendt "speech and action" are integral to the definition of being human — both take place with others and thus both affirm the original status of relationality - they also indicate why, from Arendt's perspective, it makes little sense to argue that the slave can be virtuous when the slave is by definition excluded from full participation in the place of life. And yet, despite elements of his argumentation, it can be suggested that the slave's vulnerable body is a constitute element of their being of which Seneca is aware. (This latter will emerge.)

If nudity is taken as a form of exposure then while the soul should appear as it is, presence as self presence, Seneca is keenly aware that the body demands that form of care in which nudity as exposure should be avoided. Hence in De vita beata he notes, "I would rather show [ostendere] the state of my soul [mihi animi] clad rather in a toga and shoes than showing naked shoulders [nudis scapulis] and with cuts on my feet" $(25.2)^{32}$ The point is straightforward. The state of the soul, while indifferent to the body's predicament, cannot efface the body's own vulnerability. Clothing becomes both the acknowledgment and the engagement with that state of affairs. This most compelling account of human vulnerability occurs in Epistulae morales 95. In a direct engagement with the nature of human being, Seneca notes in an account of human cruelty and the repositioning of death as a form of sport that this occurs despite the fact that the human is 


\section{REDRESSING THE METAPHYSICS OF NUDITY}

a "sacred thing" (sacra res) in the eyes of others. (Here, of course, is the identification of the scared with mere human presence in a way that has no effect. It is as though the human is pointlessly sacred. The sacred is not positioned within a calculus. The sacred becomes therefore the interplay of the incalculable and the fragile. This is of course Arendt's point.) For this denial of the "sacred" to have occurred, morality, he suggests, has become "perverse." Evidence for which is the training of combatants for a "spectacle" in which humans become corpses. Those who enter this arena could be described as having been produced as "naked and defenseless" (nudus inermisque, Sen. Ep. 95.33). Again there is nudity. Here, however, nudity is the mark of pure exposure, absolute fragility standing forth. It is the mark of those to be killed. This could be the body of the slave. There is therefore a doubling within nudity.

What is it to engage exposure? The answer, as will become clear, is that it is to engage this doubling. Seneca's response in the Letter involves the inculcation of virtue. This leads firstly to a discussion of the human relation to the divine, then to the engagement with specific virtues, and finally to the lives of virtuous men. In other words, the threat of exposure lead to a response situated in the gradual refining of the specificity of human being. That specificity is of course located in the human as a singularity. Note for example the argument that "conduct will not be right unless the will [voluntas] to act is right $[$ recta $]$ for this is the source of conduct. Not again can the will be right without the right attitude of the soul [animi]; for this is the source of the will” (Sen. Ep. 95.57). This, however, is unsatisfactory. The right attitude of the soul is not a defense for those who are "thrust forth naked and defenceless." The only counter to such a set-up involves breaking with a form of reciprocity that demands equality since that structure has already 


\section{REDRESSING THE METAPHYSICS OF NUDITY}

broken down. This is the crucial point.

Aristotle accounts for why there has been the establishment of a shrine to the Graces in a public place in the following terms: "to remind men to return a kindness; for that is a special characteristic of grace, since it is a duty not only to repay a service done one, but another time to take the initiative in doing a service oneself" (Eth. Nic. 1133a 3). In other words, there is an essential reciprocity of relation. It is precisely this point that also occurs in Seneca's account of the Three Graces in the De beneficiis (3.1-7).

Why do the sisters hand in hand dance in a ring which returns upon itself?

For the reason that a benefit passing in its course from hand to hand returns nevertheless to the giver; the beauty of the whole is destroyed if the course is anywhere broken, and it has most beauty if it is continuous and maintains an uninterrupted succession.

Here is a modality of relation. Equally, this is another instance of the metaphysics of nudity since in Seneca's formulation "the maidens wear flowing robes, and these, too, are transparent because benefits desire to be seen." They are for all intents and purposes naked. This does, of course, account for the presence of the Three Graces in Botticelli's Primavera. ${ }^{33}$

Nudity, therefore, can neither aid nor diminish the threat of exposure. Exposure as a threat is, after all, the other modality of nudity. It cannot be overcome by any evocation of "the naked human being." Indeed, it can be argued that Seneca realized that when he noted that the presence of the human as a "sacred thing" could always be refused. 


\section{REDRESSING THE METAPHYSICS OF NUDITY}

Evidence of this refusal, the forgetting of the "sacred," was the production, and it should be noted that it is a form of production, of given human beings as both "naked" and “defenseless." The response to nudity is neither clothing nor a reinvestment in nudity's presence as an exemplification of the sacred. The status of the ethical subject remains the same in both instances. The response is the refusal of the centrality of the putative primacy of the subject as original (and originally naked). In other words, the response inheres in attributing centrality not to the relation that effaces the differences that carry within them disequilibria of power (e.g., slave/freeman) but to that other form of relation that is marked by an insistent having-to-appear that needs guarantees rather than being assumed as axiomatic. This is the mode of relationality that for Arendt circumscribes the cogency of Roman political thought; namely the originality of the "inter" in the formulation "inter homines esse." The rethinking of dignity has to incorporate therefore the affirmation of this specific mode of relationality whilst recognizing that appearance continues as an insistent and urgent question. 


\section{LITERATURE CITED}

Arendt, Hannah. 1951. The Origins of Totalitarianism. New York.

-1958. The Human Condition. Chicago.

- 1971. The Life of the Mind. New York.

Asmis, Elizabeth. 1990. Seneca's On the Happy Life and Stoic Individualism. Apeiron 23: $219-55$.

Bartsch, Shadi, and David Wray, eds.. 2009. Seneca and the Self. Cambridge.

Batinski, Emily E. 1993. Seneca's Response to Stoic Hermeneutics. Mnemosyne 46: 6977.

Benjamin, Andrew. 1993. The Plural Event. London.

. 2010. Of Jews and Animals. Edinburgh.

—. 2015. Towards a Relational Ontology: Philosophy's Other Possibility. Albany, NY.

- 2016a. The Problem of Authority in Arendt and Aristotle. Philosophy Today 60: 253-76.

. 2016b. Virtue in Being. Albany, NY.

—. 2017a. Oikonomia, Incarnation and Immediacy: The Figure of the Jew in St John of Damascus. International Journal of Philosophical Studies 25: 407-22.

- 2017b. The Predicament of Life: Dennis Schmidt and the Ethical Subject. Epoché 22: 67-78. 


\section{REDRESSING THE METAPHYSICS OF NUDITY}

Bernasconi, Robert. 2008. Extra-Territoriality: Outside the State, Outside the Subject. In Levinas Studies: An Annual Review, vol. 3, ed. Jeffery Blochel, 167-81. Pittsburgh.

Bernstein, Richard. 1996. Hannah Arendt and the Jewish Question. Cambridge. Birmingham, Peg. 2006. Hannah Arendt and Human Rights: The Predicament of Common Responsibility. Bloomington, IN.

Dempsey, Charles. 1971. Botticelli’s Three Graces. JWarb 34: 326-30.

Dyson, Stephen. 1970. The Portrait of Seneca in Tacitus. Arethusa 3: 71-84.

Foucault, Michel. 1994. Histoire de la sexulaité. Vol. 3, Le Souci de soi. Paris.

Griffin, Miriam, T. 2013. Seneca on Society: A Guide to "De Beneficiis." Oxford.

Haase, F., ed. 1853. L. Annaei Senecae opera quae supersunt. Vol. 3. Leipzig.

Hadot, Pierre. 2002. Exercices spirituels et philosophie antique. Paris.

Hammer, Dean. 2002. Hannah Arendt and Roman Political Thought: The Practice of Theory. Political Theory 30: 124-49.

Levinas, Emmanuel. 1990. Totalité et Infini. Paris.

Plett, Heinrich F. 2012. Enargeia in Classical Antiquity and the Early Modern Age: The Aesthetics of Evidence. Leiden.

Ramelli, Ilaria. 2009. Hierocles the Stoic: “Elements of Ethics," Fragments, and Excerpts. Trans. David Konstan. Atlanta.

Rosenmeyer, Thomas G. 2000. Seneca and Nature. Arethusa 33: 99-119.

Russell, Daniel C. 2004. Virtue as "Likeness to God" in Plato and Seneca. Journal of the History of Philosophy 42: 241-60.

Schmidt, Dennis. 2005. Lyrical and Ethical Subjects. Albany, NY. 


\section{REDRESSING THE METAPHYSICS OF NUDITY}

Schofield, Malcolm. 2015. Seneca on Monarchy and the Political Life: De Clementia, De Tranquillitate Animi, De Otio. In The Cambridge Companion to Seneca, ed. Shadi Bartsch and Alessandro Schiesaro, 68-81. Cambridge.

Stanley, Gregory A. 2010. Seneca and the Idea of Tragedy. Oxford.

Topolski, Anya. 2015. Arendt, Levinas and a Politics of Relationality. London.

Walker, Denis Henry. 1963. Tacitus and Seneca. GaR 10: 98-110. 


\section{REDRESSING THE METAPHYSICS OF NUDITY}

${ }^{1}$ The term ethical subject is used here to outline a field of inquiry. Central to the overall project will be an engagement both with how this term is used by Dennis Schmidt and how he distinguishes between what he calls the "ethical subject" and the "lyrical subject." Both of which are instances of the thinking of what is referred to here as the ethical subject. See Schmidt 2005. I engage directly with Schmidt's work in Benjamin $2017 \mathrm{~b}$. ${ }^{2}$ This is the position I have tried to argue in my Virtue in Being. See Benjamin $2016 \mathrm{~b}$. ${ }^{3}$ Arendt 1958, 7. For a sustained examination of Arendt's relation to Roman philosophy see Hammer 2002. The important point to note, as Hammer makes clear, is that Arendt's relation to Roman thought involved a commitment to the implicit conception of history and thus historical time that occurred within it rather than any sustained engagement with any conception of self.

${ }^{4}$ See to this end Benjamin 2016a.

${ }^{5}$ While the project of this paper is to begin to develop a specific formulation of the conception of the self in Seneca, in part this is to be able to contest the singularity of the self that occurs in his writings to the conception of the plural and relational self in Arendt, it should not be thought that there has not already been a sustained engagement within Seneca's conception of the self. For an overview of this project, one that covers all aspects of Seneca's writings, see the papers collected in Bartsch and Wray 2009.

${ }^{6}$ Even though it cannot be done in the context of this paper, clearly what would need to be taken up here is the work of both Michel Foucault and Pierre Hadot. What remains as open questions is the extent to which an attempt to redeploy the ethical implication of "self-care" can escape the primacy of the individual. See Foucault 1994 and Hadot 2002. 
${ }^{7}$ There is an important connection here between this conception of liberty and the development in De beneficiis of giving "benefits" as an act not dictated by obligation but by a form of freedom. See Griffin 2013, 23.

${ }^{8}$ It should not be thought that this evocation of an art of life does not admit of argumentation. In Seneca De otio 1.3-2.1, while the formulation is different, in response to the position that evokes "the common good" (communi bono), Seneca responds that it is possible to withdraw from the world, contemplate truth, to live rationally (rationem vivendi) and that such activities remain consistent with Stoicism. At work here is, of course, the implicit construction of the ethical subject.

${ }^{9}$ The creation of an image to be followed or imitated is also discussed by Schofield $(2015,68-70)$. Moreover, there is an important connection between the presence of the exemplary image in Seneca's ostensibly philosophical writings and his tragedies. For a superb discussion of this connection see Stanley 2010.

${ }^{10}$ Walker 1963; Dyson 1970, 71.

${ }^{11}$ Rosenmeyer 2000.

${ }^{12}$ For a discussion of Seneca's use of Vergil and thus his recourse to a specific hermeneutic strategy, see Batinski 1993.

${ }^{13}$ Russell 2004, 252.

${ }^{14}$ Though it should be noted that in De constantia 6.8 in addressing Serenus he describes himself as "this perfect man, full of virtues human and divine" (pefectum illum virum, humanis divinisque virtutibus plenum). 
${ }^{15}$ The interesting question would be the relationship between this point and Plato's argument in the Theaetetus that links escape from the world, perhaps evasion as a form of retirement to the process of homoiosis to theo. To this end, see Pl. Tht. 176a-b. ${ }^{16}$ Asmis 1990.

${ }^{17}$ This fragment appears in Haase 1853, 421. See also the important reference in Epistulae morales 53.11, in which the relation is given a specific temporal determination: “The wise man's life spreads out to him over as large a surface as does all eternity to a God.”

${ }^{18}$ Recalled here is the presence and effect of the sun in Plato. See Resp. 507b-509c.

${ }^{19}$ See, in this instance, the discussion in Staley 2010, 58-60. For a more detailed elaboration of the term and its place in both ancient philosophy and rhetoric, see Plett 2012.

${ }^{20}$ I have discussed the work of this logic in the context of St John of Damascus in Benjamin 2017a.

${ }^{21}$ A similar structure of argumentation can also be found in Neo-Stoicism. In a fragment of Hierocles that is cited in Stobaeus' Anthology the way people are treated is premised on "supposing that one is oneself that person and that the person is oneself." The argument takes as the example that establishes the general claim of the slave. Again, there would be the assumption of a reciprocity of treatment based on the general claim of just treatment. What this allows is that conception of just treatment that sustains the presence of slavery. See Ramelli 2009, 87. 
${ }^{22}$ The counter measure is not simply oppositional. It is the response that counters the prevailing position from within the terms set by the framework that generated that position in the first place.

${ }^{23}$ Arendt 1951, 295. This line from Arendt has been subject to sustained and varying forms of discussion. See, e.g., Bernstein 1996; Birmingham 2006.

${ }^{24}$ Arendt 1971, 182.

${ }^{25}$ See Levinas 1990, 72. Moreover, the importance of Levinas can be located in the way that his departure from "possessive individualism" is formulated. In Robert Bernasconi's $(2008,176)$ terms, this occurs "by constructing the event of identity in being for another that undoes the conception of personal identity on which liberalism relies."

${ }^{26}$ For a sustained discussion the relation between Arendt and Levinas, see Topolski 2015.

${ }^{27}$ Arendt 1958, 7-8.

${ }^{28}$ Birmingham 2006, 36.

${ }^{29}$ This is a key term for Arendt. It is defined in The Human Condition thus: "The space of appearance comes into being wherever men are together in the manner of speech and action, and therefore predates and precedes all formal constitution of the public realm and the various forms of government, that is, the various forms in which the public realm can be organized" (Arendt 1958, 199).

${ }^{30}$ This term has been developed in much greater detail in my work. See Benjamin 2010; 2015. In other words, if relationality is understood as an original condition such that plurality — itself a mode of relationality—always precedes the singular, it then follows that a singularity posited as without relation is a produced state. What endures is the 
relation as anoriginal. The latter-the anoriginal — is a term that marks the presence of a founding plurality. See Benjamin 1993, 2016.

${ }^{31}$ Arendt 1958. 176.

${ }^{32}$ See, in addition, De providentia 4.13-14.

${ }^{33}$ For an account of the significance of Seneca's version of the Three Graces on the history of art and especially Botticelli, see Dempsey 1971.

\section{Classical Philology 113 (2018): XXX-XXX}

[C 2018 by The University of Chicago. All rights reserved] 0009-837X/18/11301-0004\$10.00 